\title{
Distance (Media policy/ Meta journalism)
}

\section{AUTHOR}

Stefano Pedrazzi

\section{KEYWORDS}

self-coverage, competition, news bias

\section{BRIEF DESCRIPTION}

The variable "distance" reflects the competitive relationships that exist between media organizations and outlets in terms of journalistic, economic and media policy interests, which can lead to reporting differences in media self-coverage (Pointner, 2010). This is due to the special situation that in the case of media self-coverage, both the reporting unit and the covered subject originate from the media sector. Several studies have shown that media organizations strategically use self-coverage to pursue their own interests, to legitimize their actions or to differentiate themselves from their competitors (Beck, 2001; Gilens \& Hertzman, 2000; Hackett \& Uzelman, 2003; Kemner, Scherer, \& Weinacht, 2008; Lichtenstein, 2011; Löblich, 2011; Maier \& Dogruel, 2016; Müller \& Donsbach, 2006; Pointner, 2010; Snider \& Page, 1997; Uzelman, Hackett, \& Stewart, 2005; Weiß, 1986).

\section{FIELD OF APPLICATION/THEORETICAL FOUNDATION}

The variable serves as an indicator of potential conflicts of roles, interests and objectives at organizational level, which can lead to unbalanced or biased reporting.

\section{EXAMPLE STUDY}

Pointner (2010)

\section{INFORMATION ON POINTNER, 2010}

Research interest: The study examines whether and how economic interests of media companies are reflected in the reporting on media companies.

Object of analysis: A sample (one artificial day per month, all articles covering media companies) was drawn from four national German daily newspapers.

Time frame of analysis: January 1, 1992 to December 31, 2006

\section{INFORMATION ABOUT VARIABLE \\ Level of analysis: article}

Coding logic: The relationship between the reporting unit and the covered subject is recorded on two levels. First, a distinction is made with regard to the media sector, i.e. whether the reporting concerns a subject originating from the same sector (intramedial, e.g. print observes print) or from a different sector (intermedial, e.g. print observes broadcasting). Within the intramedial level, a further distinction is made with regard to the organizational affiliation: Codes indicate whether the reporting relates to the own company (direct self-observation), affiliated companies of the own company (indirect self-observation), one or more direct competitors operating within the same media sector in the same media submarket (direct competitor observation), affiliated companies of competitors (indirect competitor observation) or media companies of other genres within the own media sector (general observation) (Pointner, 2010).

For the implementation, it is recommended to first code the outlet in which a contribution appears, as well as separately code the outlet and the media sector that is the main subject of the coverage. Based on this, the assignment can be made with the help of an affiliation list of the outlets and affiliated companies of the publishing houses, media companies or media sectors in- 
vestigated. However, it should be mentioned that in connection with the horizontal diversification of media companies into other media sectors and increasing convergence, the differentiation into intramedial and intermedial as well as direct and indirect is becoming increasingly difficult.

Values: see Table 1

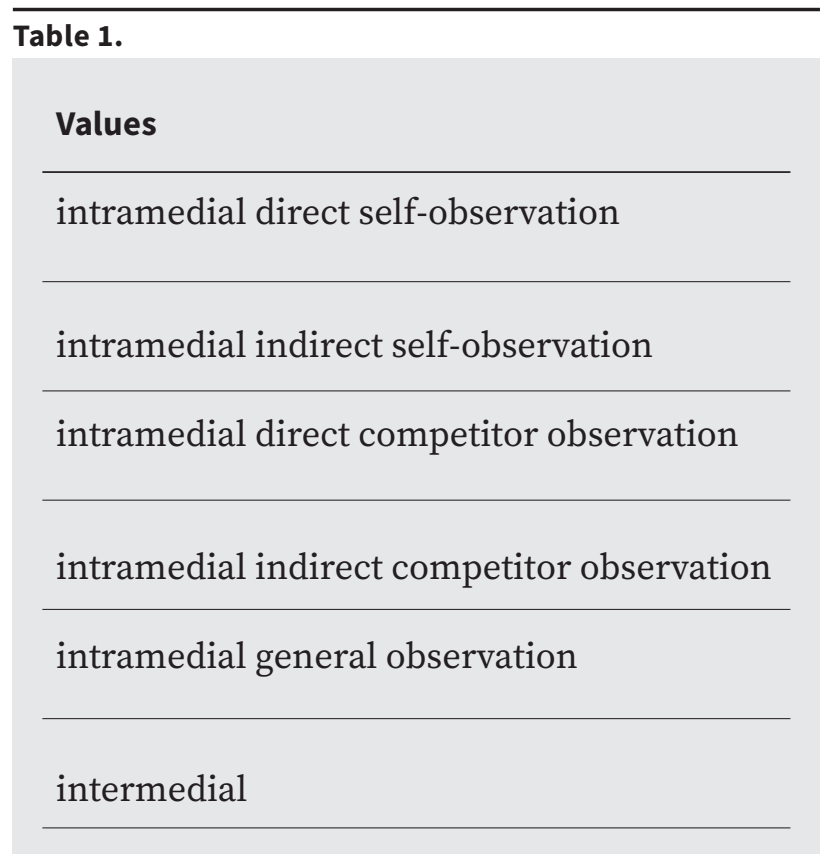

Intercoder reliability: Holsti's coefficient of .94 across categories (6 coders), not specified for individual category

Codebook not available

\section{REFERENCES}

Beck, K. (2001). Medienberichterstattung über Medienkonzentration. Publizistik, 46(4), 403-424. doi: 10.1007/s11616-001-0121-3

Gilens, M., \& Hertzman, C. (2000). Corporate Ownership and News Bias: Newspaper Coverage of the 1996 Telecommunications Act. The Journal of Politics, 62(2), 369-386. doi: 10.1111/0022-3816.00017

Hackett, R. A., \& Uzelman, S. (2003). Tracing Corporate Influences on Press Content: a summary of recent NewsWatch Canada Research. Journalism Studies, 4(3), 331-346. doi: 10.1080/14616700306486

Kemner, B., Scherer, H., \& Weinacht, S. (2008). Unter der Tarnkappe. Publizistik, 53(1), 65-84. doi: 10.1007/s11616-008-0006-9

Lichtenstein, D. (2011). Kommerzialisie- rung des Medienjournalismus? Eine empirische Untersuchung zum „Fall Berliner Zeitung“. M\&K Medien \& Kommunikationswissenschaft, 59(2), 216-234. doi: 10.5771/1615-634x-2011-2-216

Löblich, M. (2011). Frames in der medienpolitischen Öffentlichkeit. Publizistik, 56(4), 423-439. doi: 10.1007/s11616-011-0129-2

Maier, D., \& Dogruel, L. (2016). Akteursbeziehungen in der Zeitungsberichterstattung über die Online-Aktivitäten des öffentlichrechtlichen Rundfunks. Publizistik, 61(2), 145-166. doi: 10.1007/s11616-016-0258-8

Müller, D., \& Donsbach, W. (2006). Unabhängigkeit von wirtschaftlichen Interessen als Qualitätsindikator im Journalismus. In S. Weischenberg, W. Loosen, \& M. Beuthner (Eds.), Medien-Qualitäten: Öffentliche Kommunikation zwischen ökonomischem Kalkül und Sozialverantwortung (pp. 129-147). Konstanz: UVK.

Pointner, N. (2010). In den Fängen der Ökonomie? Ein kritischer Blick auf die Berichterstattung über Medienunternehmen in der deutschen Tagespresse. Wiesbaden: VS Verlag für Sozialwissenschaften.

Snider, J. H., \& Page, B. I. (1997). Does Media Ownership Affect Media Stands? The Case of the Telecommunications Act of 1996. Institute for Policy Resarch at Northwestern University (IPR working papers 97-12).

Uzelman, S., Hackett, R. A., \& Stewart, J. (2005). Covering Democracy's Forum: Canadian Press Treatment of Public and Private Broadcasting. Critical Studies in Media Communication, 22(2), 156169. doi: 10.1080/07393180500072053

Weiß, H.-J. (1986). Rundfunkinteressen und Pressejournalismus. Abschließende Analysen und Anmerkungen zu zwei inhaltsanalytischen Zeitungsstudien. Media Perspektiven, 2(86), 53-73. 